\title{
RESPON PEMBERIAN TEPUNG DAUN KELOR (Moringa oleifera) PADA PAKAN AYAM PETELUR TERHADAP PENAMPILAN PRODUKSI DAN KUALITAS TELUR
}

\section{EFFECT OF MORINGA (Moringa oleifera) LEAF MEAL SUPPLEMENTATION IN LAYER CHICKEN DIET ON PRODUCTION PERFORMANCE AND EGG QUALITY}

\author{
Edi Wahyu Satria*, Osfar Sjofjan, dan Irfan Hadji Djunaidi \\ Jurusan Nutrisi dan Makanan Ternak, Fakultas Peternakan, Universitas Brawijaya, Malang, 65145
}

Submitted: 15 May 2016, Accepted: 3 October 2016

\section{INTISARI}

Tujuan penelitian ini adalah mengetahui pengaruh pemberian tepung daun kelor (Moringa oleifera) dalam pakan terhadap penampilan produksi dan kualitas telur pada layer. Materi yang digunakan adalah ayam petelur umur 38 - 42 minggu strain Isa Brown produksi PT. Charoen Pokphand sebanyak 120 ekor; pakan yang disusun dari konsentrat : jagung : bekatul : mineral tepung daun kelor dengan perbandingan $30: 36: 31: 3$. Rancangan yang digunakan adalah eksperimental dengan pencampuran pakan basal tanpa Moringa oleifera untuk control $\left(\mathrm{P}_{0}\right)$, penambahan Moringa oleifera 0,5\% $\left(\mathrm{P}_{1}\right), 1 \%\left(\mathrm{P}_{2}\right), 1,5 \%\left(\mathrm{P}_{3}\right)$ dan $2 \%\left(\mathrm{P}_{4}\right)$. Variabel yang diamati adalah penampilan produksi dan kualitas telur. Untuk mengetahui pengaruh pemberian tepung daun kelor pada pakan digunakan analisis of varians (ANOVA) dengan Rancangan Acak Lengkap pola searah. Apabila terdapat perbedaan rerata antar perlakuan dilakukan uji Duncan. Hasil penelitian menunjukkan bahwa pemberian tepung daun kelor pada ayam petelur dapat meningkatkan produksi dan kualitas telur. Penambahan tepung daun kelor dalam pakan sebesar $2 \%$ memberikan efek terbaik terhadap penampilan produksi dan kualitas telur, disarankan penambahan tepung daun kelor dalam pakan sebesar $2 \%$ agar memperoleh penampilan produksi dan kualitas telur dengan hasil terbaik.

(Kata kunci: Layer, Pakan, Produksi, Tepung daun kelor)

\section{ABSTRACT}

The purpose of this study was to determine the effect of Moringa leaf meal (Moringa oleifera) in feed on production performance and egg quality of laying hens. The materials used 120 laying hens of Isa Brown breed in 38 to 42 weeks age. The method used an experimental trial by Moringa oleifera addition in the basal feed. The experiment were devided into four groups i.e. without Moringa oleifera as control (PO), with Moringa oleifera 0.5\% (P1), 1\% (P2), 1.5\% (P3) and 2\% (P4). Variables observed were the appearance of egg production and quality. The data was analyzed by Completely Randomized one way design. The mean differences were calculated by the Duncan Multiple Range Test. The results showed that administration of Moringa leaf powder can increase the production and quality of eggs in laying hens. Addition of 2\% Moringa leaf powder in the feed gives the best effect on the appearance and quality of production and egg. This research suggested the addition of $2 \%$ Moringa leaf powder was recommended in order to obtain the finest appearance and quality of production.

(Key words: Feed, Laying hens, Moringa leaf meal, Production)

\footnotetext{
* Korespondensi (corresponding author):

Telp. +62 87863686990

E-mail: wahyusatria1207@gmail.com
} 


\section{Pendahuluan}

Penggunaan bahan pakan yang berkualitas diperlukan untuk meningkatkan produksi ternak. Pakan komersial yang berkualitas sangat tergantung pada harga bahan baku pakan yang diimpor sehingga rawan terhadap kenaikan harga. Oleh karena itu, diperlukan langkah alternatif untuk menekan biaya pakan namun tetap mempertahankan kualitas pakan dan penampilan produksi ternak tetap tinggi. Salah satu langkah yang dapat dilakukan untuk meningkatkan penampilan produksi ternak adalah dengan tetap mempertahankan kualitas dan kuantitas pakan dan menambahkan feed additives dalam pakan.

Daun kelor (Moringa oleifera, lam) belum banyak digunakan dalam pakan ternak terutama untuk pakan unggas. Tanaman kelor merupakan tanaman perdu yang banyak dijumpai di Indonesia sebagai tanaman pagar yang mempunyai banyak manfaat. Daun dan buah kelor telah lama digunakan oleh masyarakat sebagai sayur. Hasil penelitian yang dilakukan di Afrika menunjukkan bahwa daun kelor mengandung vitamin $\mathrm{C}$ tujuh kali lebih banyak dari buah jeruk, mengandung empat kali kalsium lebih banyak dari susu, empat kali vitamin A dalam wortel, dua kali protein dalam susu dan tiga kali potasium dalam pisang (Anonim, 2005).

Ketersediaan daun kelor yang cukup melimpah serta tersedia sepanjang tahun menjadi salah satu pertimbangan untuk dapat dimanfaatkan sebagai bahan campuran dalam pakan yang relatif murah. Daun kelor mengandung gula sederhana, rhamnose, dan senyawa unik yaitu glukosinolat dan isotiotianat serta diketahui sebagai hipotensif, anti kanker dan aktivitas antibakteri yang meliputi 4- $(\alpha-$ Lrhamnopyranosyloxy) benzyl isothiocyanate, pterygospermin, dan 4-( $\alpha-L-$ rhamnopyranosyloxy) benzylglucosinolate berpotensi (Soetanto, 2005). Penelitian yang dilakukan oleh Sjofjan (2008) menunjukkan bahwa pemberian daun kelor dalam pakan memberikan peningkatan terhadap konsumsi pakan, pertambahan bobot hidup, konversi pakan, berat karkas, faktor efisiensi produksi dan income over feed cost (IOFC). Penggunaan hingga $10 \%$ tepung daun kelor dalam pakan tidak memberikan efek negatif dalam penampilan produksi ayam pedaging.

Penelitian tentang pemberian tepung daun pada pakan ayam petelur yang 198 bertujuan untuk meningkatkan kualitas telur yang sampai saat ini belum pernah dilakukan. Penelitian ini membahas tentang pemberian tepung daun kelor sebagai pakan ayam petelur yang dicampurkan dengan pakan ayam petelur sehingga diharapkan dengan pemberian tepung daun kelor (Moringa oleifera) dalam pakan dapat meningkatkan kualitas produksi dan kualitas telurnya.

\section{Materi dan Metode}

Materi yang digunakan dalam penelitian ini adalah ayam petelur sebanyak 120 ekor umur 38 - 42 minggu strain Isa Brown produksi PT. Charoen Pokphand. Pakan disusun dari konsentrat : jagung : bekatul : mineral dengan perbandingan 30 : 36 : 31 : 3, dan tepung daun kelor. Konsentrat yang digunakan adalah konsentrat ayam petelur periode layer dengan kode produksi K 204 X-TRA yang diproduksi oleh PT. Sierad Sidoarjo. Metode penelitian yang digunakan adalah eksperimen dengan menggunakan rancangan percobaan Rancangan Acak Lengkap dengan 5 perlakuan dan 4 ulangan. Masing-masing ulangan terdiri dari 6 ekor ayam. Perlakuan dalam penelitian ini adalah $\mathrm{P}_{0}$ : pakan basal tanpa penambahan tepung daun kelor; $\mathrm{P}_{1}$ : pakan basal 99,5\% + tepung daun kelor 0,5\%; $\mathrm{P}_{2}$ : pakan basal $99 \%+$ tepung daun kelor $1 \%$; $\mathrm{P}_{3}$ : pakan basal $98,5 \%$ + tepung daun kelor 1,5\%; dan $\mathrm{P}_{4}$ : pakan basal $98 \%$ + tepung daun kelor $2 \%$.

Variabel yang diamati dalam penelitian ini adalah penampilan produksi yang terdiri dari konsumsi pakan, produksi telur (HDP), konversi pakan, income over feed cost (IOFC) dan kecernaan Protein. Variabel kualitas telur pada layer yang diamati adalah kualitas telur eksterior yang terdiri dari bobot telur dan bobot dan indeks telur sedangkan pengamatan kualitas interior telur terdiri dari warna kuning telur, berat kerabang telur, tebal kerabang telur, indeks kuning telur dan kandungan kolesterol kuning telur. Data yang diperoleh ditabulasi kemudian dilakukan analisis statistik dengan ANOVA menggunakan Rancangan Acak Lengkap dan apabila terdapat perbedaan pengaruh antar perlakuan dilanjutkan dengan uji Duncan's (Astuti, 2007).

\section{Hasil dan Pembahasan}

Hasil penelitian menunjukkan bahwa penambahan tepung daun kelor (Moringa 
oleifera) pada pakan memberikan pengaruh yang sangat nyata $(P<0,01)$ terhadap konsumsi dan konversi pakan tetapi tidak memberikan pengaruh $(P>0,05)$ terhadap hen day production dan IOFC pada ayam petelur. Rerata konsumsi pakan ayam petelur tertinggi terdapat pada perlakuan $\mathrm{P}_{4}$ (penambahan tepung daun kelor sebanyak $2 \%)$. Pada umumnya ayam meningkatkan konsumsi untuk memenuhi kebutuhan energinya. Apabila dilihat dari tingginya kandungan energi pada ransum komersial yang disubstitusi $2 \%$ daun kelor, menunjukkan bahwa tingginya konsumsi pada ayam yang diberi ransum bukan dikarenakan kebutuhan energi yang belum tercukupi. Hasil tersebut kemungkinan karena ada peningkatan kecernaan ransum pada ransum komersial yang disubstitusi dengan $2 \%$ daun kelor. Hasil analisis yang lain adalah ada peningkatan palatabilitas pada ransum komersial yang disubstitusi sehingga merangsang ayam untuk meningkatkan konsumsinya. Hasil pengujian pengaruh pemberian tepung daun kelor terhadap produktivitas ayam petelur menghasilkan data seperti yang terlihat pada Tabel 1.

Pemberian tepung daun kelor memberikan pengaruh yang sangat nyata $(P<0,01)$ terhadap konversi pakan pada ayam petelur. Konversi pakan tertinggi terdapat pada perlakuan $\mathrm{P}_{4}$ sebesar $2,04 \pm 0,01$ sedangkan terendah di perlakuan $P_{0}$ sebesar 2,08 $\pm 0,02$. Hasil ini diperkuat oleh penelitian Kaniadewi (2006) yang melaporkan bahwa penambahan esktrak daun beluntas (memiliki zat aktif minyak atsiri, alkaloid, flavonoid, tanin dan saponin) ke dalam air minum ayam nyata menurunkan konversi ransum ayam broiler. Ayam yang mendapat perlakuan tepung daun kelor dalam ransum nilai konversi pakannya lebih baik $(2,04-2,06)$ dibandingkan dengan ransum perlakuan tanpa pemberian daun kelor $(2,08)$. Hasil menunjukkan bahwa penambahan tepung daun kelor dalam ransum dapat memperbaiki nilai konversi ransum. Konversi ransum yang terbaik dihasilkan oleh $\mathrm{P}_{4}$ sebesar 2,04 $\pm 0,01 \mathrm{di}$ mana peningkatan konsumsi ransum diikuti oleh produksi telur sehingga dapat disimpulkan bahwa $\mathrm{P}_{4}$ mempunyai efisiensi penggunaan ransum yang paling baik dibandingkan dengan ransum kontrol. Terjadinya perbedaan rerata konversi ransum dapat dijelaskan bahwa rerata konsumsi ransum tidak dipengaruhi oleh ransum perlakuan, hasil tersebut bisa dikaitkan dengan rerata produksi (Tabel 1). Data pada Tabel 1 terlihat dengan jelas bahwa semakin tinggi kandungan tepung daun kelor dalam ransum maka semakin tinggi pula rerata produksi telur. Sebaliknya pada ayam yang mendapat ransum tanpa daun kelor, menunjukkan rerata produksi telurnya rendah, sehingga diperoleh hasil rerata konversi ransum yang kurang baik. Perlakuan $\mathrm{P}_{3}$ dan $\mathrm{P}_{4}$ memiliki konversi pakan terbaik karena nilainya yang rendah hal ini didukung dengan peningkatan yang sama pada hen day production. Konversi pakan pada $\mathrm{P}_{3}$ dan $\mathrm{P}_{4}$ yang rendah diduga disebabkan adanya senyawa aktif alkaloid yang terdapat pada daun kelor. Hal tersebut diduga dapat mempengaruhi konsumsi pakan sehingga berpengaruh terhadap hitungan nilai konversi pakan. Nesheim et al. (1979) menyatakan bahwa faktor-faktor yang mempengaruhi konversi pakan adalah kandungan energi yang cukup, kecukupan zat nutrisi dalam pakan, suhu lingkungan dan kondisi kesehatan.

Hasil pengujian pengaruh pemberian tepung daun kelor terhadap kualitas telur eksterior dapat dilihat pada Tabel 2. Hasil penelitian menunjukkan bahwa penambahan tepung daun kelor pada pakan ayam petelur memberikan pengaruh yang sangat nyata $(P<0,01)$ terhadap berat telur dan kolesterol telur tetapi tidak berpengaruh terhadap indeks telur, indeks kuning telur, berat kerabang, tebal kerabang serta indeks warna kuning telur. Hasil pengamatan menunjukkan rerata berat telur tertinggi pada perlakuan $\mathrm{P}_{4}$ $(62,16 \pm 0,35)$. Tingginya berat telur pada perlakuan $\mathrm{P}_{4}$ dikarenakan tingginya konsumsi pakan sehingga berpengaruh terhadap produksi telur. Berat telur yang tinggi pada perlakuan $\mathrm{P}_{4}$ diduga disebabkan kandungan senyawa aktif yang terdapat dalam daun kelor seperti minyak atsiri yang dapat meningkatkan produktifitas dan bekerja secara optimal sesuai kebutuhan ayam. Berat telur dalam penelitian ini lebih tinggi dengan berat telur menurut Leeson dan Summers (2005), yaitu berat telur umur ayam 25-32 minggu adalah $52 \mathrm{~g} /$ butir. Ayam yang mendapat perlakuan tepung daun kelor dalam ransum lebih tinggi berat telur dibandingkan dengan perlakuan tanpa pemberian daun kelor dalam ransum. Lesson 


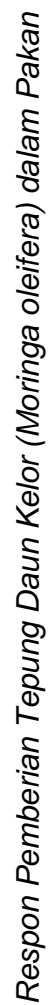
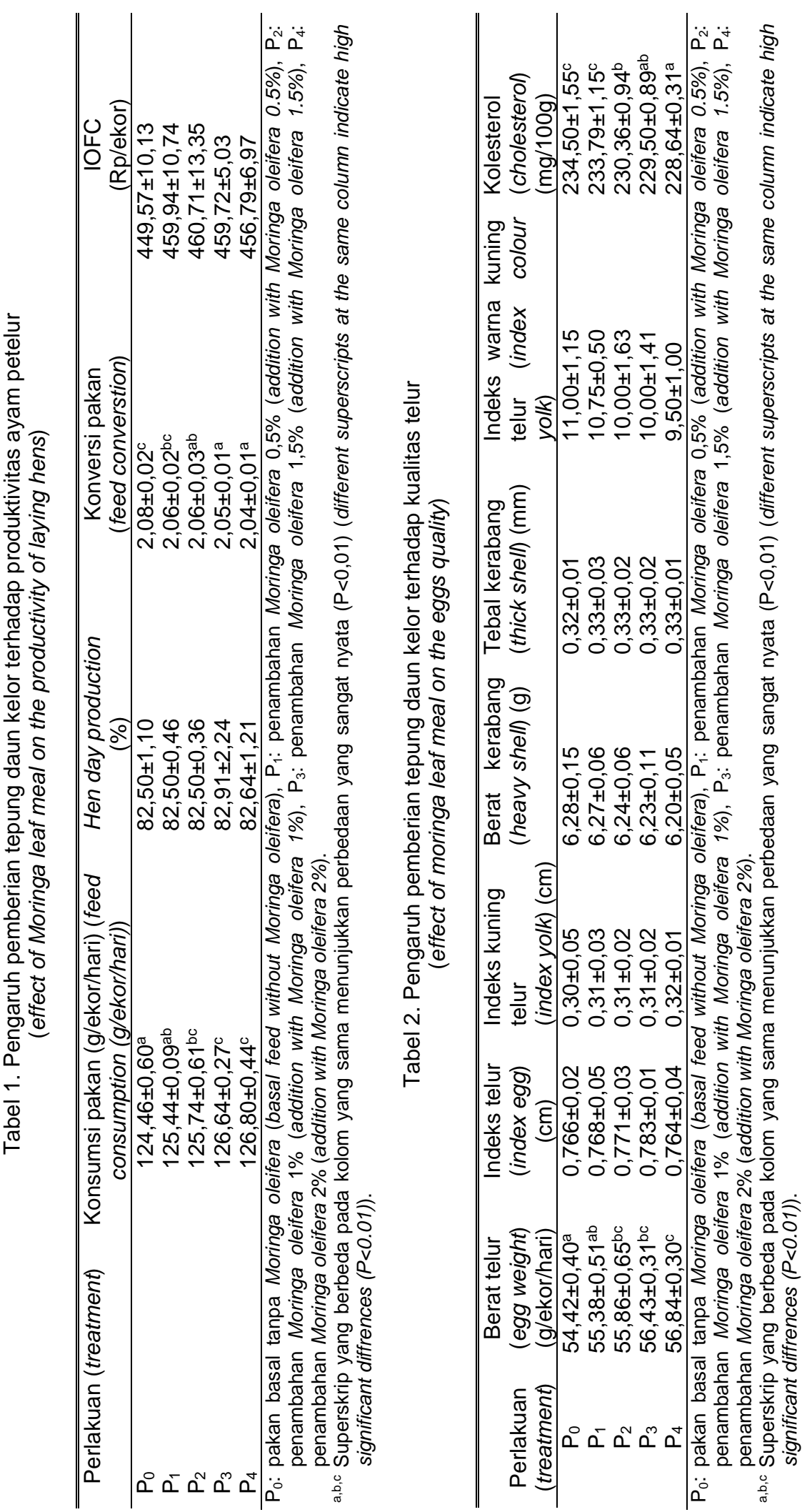
dan Summers (2001) menyatakan bahwa protein dan asam amino merupakan zat makanan yang paling berperan dalam mengontrol ukuran telur, disamping genetik dan ukuran tubuh unggas. Dengan adanya kandungan mineral pada daun kelor yang lebih besar dapat digunakan untuk meningkatkan aktivitas enzim-enzim yang terlibat dalam sintesis maupun pencernaan protein. Nakajima dan Keshavarz (1995) menyatakan bahwa mineral penting untuk meningkatkan berfungsinya enzim Pancreatic carboxypeptidase $A$ dan $B$ yang mencerna peptida-peptida menjadi asamasam amino, enzim Dipeptidase yang memecah dipeptida menjadi bentuk asamasam amino bebas dan enzim Protease yang memecah protein dalam pencernaan agar dapat diabsorpsi. Adanya peningkatan daya cerna ini mengakibatkan asupan zat-zat makanan menjadi lebih baik sehingga telur yang dihasilkan menjadi lebih besar.

Hasil yang lain dapat diamati pada kuning telur adalah mengenai warna dari kuning telur yang mengalami perubahan sesuai dengan jumlah tepung daun kelor yang terdapat dalam ransum, makin banyak tepung daun kelor yang terdapat dalam ransum, intensitas warna kuning telur semakin bertambah. Rerata skor warna kuning telur berkisar antara 9,50 - 11,00 dan secara analisis ragam tidak ada perbedaan warna kuning telur disetiap perlakuan. Semakin tinggi penambahan tepung daun kelor dalam ransum semakin baik warna kuning telur yang dihasilkan. Hal ini disebabkan karena penambahan tepung daun kelor dalam ransum akan meningkatkan kandungan vitamin A dan C dalam ransum dan akhirnya akan meningkatkan konsumsi vitamin A dan C pada ayam.

Kandungan kolesterol terendah $228,64 \pm 0,31 \mathrm{mg} / 100 \mathrm{~g}$ dihasilkan pada ransum perlakuan $\mathrm{P}_{4}$ (2\% tepung daun kelor), disini terjadi penurunan sebesar 2,56\% jika dibandingkan dengan ransum kontrol. Hasil penelitian menunjukkan bahwa semakin tinggi kandungan tepung daun, sari buah kelor dalam ransum semakin kecil kandungan kolesterol kuning telur, jika dibandingkan dengan ransum kontrol Rendahnya kadar kolesterol dalam kuning telur ini pada $\mathrm{P}_{4}$ dapat disebabkan karena adanya kandungan serat kasar yang tinggi pada tepung daun kelor. Sedangkan rendahnya kandungan kolesterol pada $\mathrm{P}_{4}$ selain adanya serat kasar, kemungkinan disebabkan oleh adanya kandungan vitamin C dalam daun kelor. Adanya vitamin $C$ ini meningkatkan produksi enzim untuk mendegradasi trigliserida sehingga trigliserida dalam serum menurun dan menguatkan dinding sel karena meningkatnya sintesis kolagen dan mukopolisakharida dalam dinding sel (Piliang dan Djojosoebagio, 2004). Menurunnya kandungan kolesterol kuning telur pada penelitian diduga disebabkan oleh serat kasar, kandungan vitamin $\mathrm{C}$, dan saponin yang terdapat pada kelor. Jadi ransum $\mathrm{P}_{4}$ (2\% tepung daun kelor) dapat menghasilkan kandungan kolesterol pada kuning telur yang lebih rendah dibandingkan dengan perlakuan lain dengan demikian kita dapat membantu masyarakat dalam mendapatkan telur yang bernilai nutrisi tinggi serta rendah kolesterol.

\section{Kesimpulan}

Berdasarkan hasil penelitian dapat disimpulkan bahwa pemberian tepung daun kelor dapat meningkatkan konsumsi dan berat telur ayam serta menurunkan konversi pakan dan nilai kolesterol kuning telur. Penambahan tepung daun kelor dalam pakan sebesar 2\% memberikan efek terbaik terhadap penampilan produksi dan dan kualitas telur ayam petelur.

\section{Daftar Pustaka}

Anonim. 2004. Cegah gizi buruk dengan konsumsi daun kelor. http//:www.portal.com. Diakses pada 25 Oktober 2014.

Astuti, M. 2007. Pengantar Ilmu Statistik untuk Peternakan dan Kesehatan Hewan. Binasti, Bogor.

Kaniadewi, R. Rd. 2006. Pengaruh pemberian ekstrak daun beluntas (Pluchea indica Less) pada air minum terhadap peforman ayam broiler pada kepadatan kandang yang tinggi. Institut Pertanian Bogor, Bogor.

Leeson, S. and J. D. Summers. 2005. Commercial Poultry Nutrition, $3^{\text {rd }}$ edn. Department of Animal and Poultry Science. University of Guelph, Canada.

Nakajima, S. and K. Keshavarz. 1995. The effect of dietary manipulations of 
energy, protein, and fat during the growing and laying periods on early eggs weight and eggs components. Poult. Sci. 74: 50-60.

Nesheim, M. C., R. E. Austic and L. E. Card. 1979. Poultry Production. $12^{\text {th }}$ edn. Lea and Febiger, Philadelphia.

Piliang, W.G. dan S.A.H. Djojosoebagio. 2004. Fisiologi Nutrisi Vol I. Bogor: Pusat Antar Universitas IImu Hayati. Institut Pertanian Bogor, Bogor.
Soetanto, H. 2005. Potensi tanaman kelor (Moringa oleifera, Lam) sebagai sumber pakan dan pangan di Indonesia. Prosiding Seminar AINI V. Universitas Brawijaya, Malang.

Sjofjan, O. 2008. Efek penggunaan tepung daun kelor (Moringa oeifera) dalam pakan terhadap penampilan produksi ayam pedaging. Seminar Nasional Teknologi Peternakan dan Veteriner, Bogor. 